\title{
Studies on the treatment of waste slurries containing heavy metal
}

\author{
Andrzej Paszek \\ Institute of Inorganic Chemistry, ul. Sowińskiego 11, 44-101 Gliwice, Poland, tel. +48 322313051 , \\ fax: +4832 23175 23, e-mail: apaszek@ichn.gliwice.pl
}

Immobilization of heavy metals in the waste with the use of cement matrix has been investigated. The quality of the obtained granulated products has been assessed and the possible areas of application have been indicated.

Keywords: waste treatment, immobilization, heavy metal.

Presented at VII Conference Wasteless Technologies and Waste Management in Chemical Industry and Agriculture, Międzyzdroje, 12 - 15 June, 2007.

\section{INTRODUCTION}

Hazardous waste, the separate components of which are not reclaimed, is usually treated by immobilizing noxious constituents and solidification. Treatment methods consist in processing the waste, which often has the form of a slurry, into an environmentally inert solid material which complies with regulatory requirements ${ }^{1}$.

The mechanism of ion (mainly heavy metal ion) immobilization in cement matrix is accompanied by many physical and chemical phenomena, such as:

- precipitatation of sparingly soluble metal hydroxides in the slightly alkaline environment,

- formation of sparingly soluble calcium compounds, e.g. fluorides, zincates,

- formation of complex compounds by hydrated calcium aluminates: $3 \mathrm{CaO} \cdot \mathrm{Al}_{2} \mathrm{O}_{3} \cdot \mathrm{CaX} \cdot \mathrm{nH}_{2} \mathrm{O}$ and $3 \mathrm{CaO} \cdot \mathrm{Al}_{2} \mathrm{O}_{3} \cdot \mathrm{CaY}_{2} \mathrm{nH}_{2} \mathrm{O}$, where $\mathrm{X}, \mathrm{Y}$ are ions bound in the complex structure,

- physical entrapment of various components (e.g. chlorides, sulphates) in cement grout, mainly by colloidal phase of $\mathrm{CaO} \cdot \mathrm{SiO}_{2} \cdot \mathrm{H}_{2} \mathrm{O}(\mathrm{C}-\mathrm{S}-\mathrm{H})^{2}$.

The composition of the mixture used for immobilization is tailored to the anticipated adverse effects of individual constituents of the waste. Pozzolanic additives, e.g. fly ash, have favourable effect on the reduction of leaching of metals from cement grout ${ }^{2}$.

The properties that determine fly ash suitability are the contents of calcium, sulphur, silicon and aluminium.

Admixture of fly ash:

- increases the resistance of concrete mix to sulphatecontaining corrosive environment,

- enables the reduction of the amount of cement used,

- improves the workability of the concrete mix.

The current BREF reference documents on non-ferrous metallurgy ${ }^{3}$ and on waste management ${ }^{4}$ specify the immobilization of hazardous components of waste as one of the best available techniques (BAT).

\section{EXPERIMENTAL}

A number of laboratory scale tests of the treatment of waste slurry from zinc hydrometallurgy process (HMN „Szopienice” S.A. in Katowice) containing heavy metals were run. The waste treatment method adopted was: immobilization of noxious waste components in a cement matrix, solidification of the slurry and obtaining the granulated form of the solid.

Waste characteristics are given in Table 1.

Table 1. Waste sample analysis results

\begin{tabular}{|l|c|c|}
\hline \multirow{2}{*}{$\begin{array}{l}\text { Component } \\
\text { determined }\end{array}$} & \multicolumn{2}{|c|}{ Component content (\%) } \\
\cline { 2 - 3 } Zinc & Sample 1 & Sample 2 \\
\hline Cadmium & 9.60 & 19.51 \\
\hline Copper & 0.35 & 0.22 \\
\hline Lead & 0.45 & 0.24 \\
\hline Nickel & 7.90 & 7.47 \\
\hline Moisture & 0.006 & 0.004 \\
\hline
\end{tabular}

\begin{tabular}{|l|c|c|}
\hline \multicolumn{3}{|c|}{ Water extract characteristics: } \\
\hline $\begin{array}{l}\text { Sulphates } \\
{\left[\mathrm{mg} / \mathrm{dm}^{3}\right]}\end{array}$ & 1530 & 1220 \\
\hline $\mathrm{pH}$ & 5.74 & 5.87 \\
\hline
\end{tabular}

\section{APPARATUS AND TEST METHOD}

Laboratory equipment used for the preparation of component mixtures and for granulation included: mixer, kneader, plate granulator and mixer-granulator.

Materials used in the process included: quicklime, fly ash and the selected grades of Portland cement (CEMI32,5R, CEMI42,5R) and blended slag-Portland cement CEMIIBS32,5R.

A series of batch tests on obtaining the granulated waste were carried out by mixing the waste with the neutralizing and solidifying additives in various proportions. The following goals were sought when determining the composition of the mixture to be granulated:

- minimize the amount of additives used,

- attain moisture content in the mixture enabling immediate granulation,

- obtain the granulated product of appropriate strength,

- maintain the chemical composition of water extract from the granulated product in compliance with wastewater requirements.

The granulated product, after seasoning, was tested to verify its suitability for the deposition in abandoned workings of underground mines, for ground levelling or for use as an aggregate for concrete mixes for car parks and internal roads.

An Erweka TBH-20 device was used to determine the compressive strength of the granulated material by measuring the disintegrating force, and compressive strength 
was calculated. The following properties of the granulated waste were determined:

- the content of grains less than $0.1 \mathrm{~mm}$ in size and susceptibility to washing out after 30 minutes - the parameters specified in the Polish standard PN-93/G-11010 „Mining. Hydraulic filling materials. Requirements and testing"

- the chemical composition of the granulated product water extract obtained as per the Polish standard PN-Z15009:1997.

\section{DISCUSSION OF GRANULATION RESULTS - PROD- UCT CHARACTERISTICS}

Arriving at the optimum moisture content in the material before granulation enabled proper blending of the components and subsequent granulation. Moisture content in the material before granulation was controlled by the amount of fly ash $(100-400 \mathrm{~g} / 1000 \mathrm{~g}$ waste $)$; the part of cement was stable. The optimum moisture content was defined as $20 \%$. No caking was observed during the seasoning of the granulated material.

The use of fly ash enabled the reduction of the amount of cement used and added to the blendability of the mixture. In particular runs the amount of cement was varied in range $25-200 \mathrm{~g} / 1000 \mathrm{~g}$ waste.

Quicklime content $(5,0-7,5 \mathrm{~g} / 1000 \mathrm{~g}$ waste) allowed to obtain the required mixture alkalinity, as the water extract of the granulated products does show the presence of heavy metals.

The conclusions - optimum mixture composition before granulation is as below:

$$
\begin{array}{ll}
\text { - fly ash } & 200 \mathrm{~g} / 1000 \mathrm{~g} \text { waste } \\
\text { - cement (CEMI32,5R) } & 50 \mathrm{~g} / 1000 \mathrm{~g} \text { waste } \\
\text { - quicklime } & 7,5 \mathrm{~g} / 1000 \mathrm{~g} \text { waste. }
\end{array}
$$

The amounts of cement and fly ash used had an effect on the strength of the granules and on the time needed to attain that strength. The compressive strength of the granules was determined by means of a device that measured the force that caused the disintegration of the granules. The compressive strength of the granules was calculated. The BAT reference documents on waste management specify that the compressive strength of the solidified waste should not be less than $1 \mathrm{MPa}$.

Most of grain samples obtained with the use of CEMI32,5R cement attained the required strength after just 7 days of seasoning.

The use of CEMI42,5R cement had slightly increased the strength and shortened the time during which that strength was attained. The use of CEMIIBS32,5 cement had increased the resistance of granules to adverse effects of sulphates. However, maximum strength was attained after a longer time.

Other indicators of material suitability for use as a fill material for underground mines are its susceptibility to washing out (determined according to PN-93/G-11010), which should not exceed $20 \%$, and the content of grains less than $0.1 \mathrm{~mm}$ in size (permissible value $20 \%$ ). All the granulated products obtained in the laboratory met these requirements.
Analysis of the water extract of the granulated product did not show the presence of any hazardous constituents. Regulations pertaining to wastewater discharge to water bodies and the PN-93/G-11010 standard require that metal content be lower than permissible, which is specified at $2.0 \mathrm{mg} / \mathrm{dm}^{3}$ for zinc, $0.5 \mathrm{mg} / \mathrm{dm}^{3}$ for lead, $0,10 \mathrm{mg} / \mathrm{dm}^{3}$ for cadmium and $500 \mathrm{mg} / \mathrm{dm}^{3}$ for sulphates.

Experience gained in laboratory tests of waste treatment was utilized to carry out technical scale tests, which were performed on an Eirich mixing and granulating device. The granulated products obtained, effectively immobilized heavy metals.

The diagram in Figure 1 illustrates the concept of the waste treatment method. The waste slurry is drawn from the disposal site and transferred to the treatment plant. The components - lime, fly ash and cement - are mixed and then blended with the waste. Mixing of dry components and blending with the waste is performed in a continuous manner. Water is added to the dry mixture during blending with the waste in order to ensure an appropriate moisture content. The moist mixture, after homogenizing, is granulated and then seasoned.

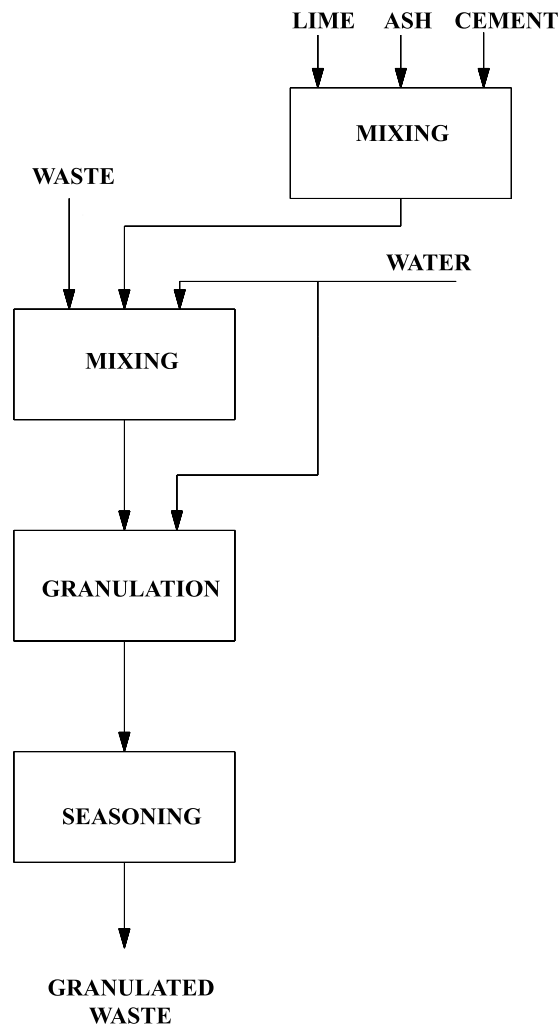

Figure 1. Block diagram of the waste utilization process LITERATURE CITED

(1) Stępniak S.: Safe disposal by solidification of sludgeform hazardous waste. Ochrona powietrza i problematyka odpadów, 1997, 2, 59 - 63 .

(2) Conner J. R.: Chemical Fixation and Solidification of Hazardous Wastes. New York. 1990.

(3) BAT reference document for non-ferrous metals manufacture, European Commission, 2001.

(4) BAT reference document for waste treatment and utilization, Ministry of Environment, 2005.

Table 2. The compressive strength of granules produced with the various cement grades after 28 days of seasoning

\begin{tabular}{|c|c|c|c|}
\hline \multirow{2}{*}{ Sample no. } & \multicolumn{3}{|c|}{ Compressive strength of granules (in MPa) depending on cement grade used } \\
\cline { 2 - 4 } & CEM I 32,5 R & CEM I 42,5 R & CEM II BS 32,5 R \\
\hline I & 1.33 & 1.94 & 1.22 \\
\hline II & 1.45 & 1.54 & 1.38 \\
\hline III & 1.14 & 1.37 & 1.27 \\
\hline
\end{tabular}

